\title{
Induction Motor Control using SVPWM Quasi Z Source Current Fed Inverter
}

\author{
R.Sathish ${ }^{1}$, R.Ilango ${ }^{2}$ \\ Assistant Professor, Department of EEE, Dhanalakshmi Srinivasan Institute of Technology, Trichy, Tamilnadu, India ${ }^{1}$ \\ Professor, Department of EEE, K.Ramakrishnan College of Engineering, Trichy, Tamilnadu, India ${ }^{2}$
}

\begin{abstract}
This paper presents the simulation model for speed control of induction motor using SVPWM Quasi Z source inverter. Here the DC input voltage is boosted by using quasi $\mathrm{Z}$ network and the output of the quasi $\mathrm{Z}$ source network is applied to the three phase SVM based inverter. The variable voltage, variable frequency AC output of the inverter is used to control the speed of the induction motor. The simulation results with $\mathrm{R}$ load and induction motor load are considered for analysis. The three phase LC filter is suggested at the output to reduce the harmonics. The THD of SVM based drive system is compared with that of the SPWM inverter based system. The proposed system performance is tested using MATLAB/SIMULINK.
\end{abstract}

Keywords: Induction Motor, Quasi Z Source, PWM, SPWM

\section{INTRODUCTION}

The quasi-Z-Source current fed inverter is normally suitable for motor drive applications, since it can buck and boost the voltage by one stage instead of using two-stage voltage source inverter[1]. The two types of modulation methods suitable for current and voltage source inverter are Carrier-Based Regular Sampled Method (CBRSM) and Space Vector Pulse Width Modulation method (SVPWM). The CBRSM includes continuous PWM [2] and discontinuous PWM [3]. The SVPWM is discussed in [4], [5]-[7]. Two generalized discontinuous carrier-based pulse width modulation (GDPWM) methodologies are proposed to reduce the switching frequency further by $1 / 3$ for current fed inverters. [8]. In a single-phase grid connected CSI, active nonlinear modulation technique is employed for reducing the low-order harmonics of input current [9].

A flexible switching pattern based on SVPWM for grid-connected CSI control is discussed in [10]. A hybrid switching scheme that combines the advantages of unipolar switching scheme and bipolar switching scheme being applied to gridconnected current-source inverters is discussed in [11]. In high power motor drive application, a selective harmonic elimination (SHE) or a combined SHE and SVPWM are usually used for the CSI modulation, in order to minimize the dc-link current [12]. For current source inverter shunt active power factor application, a new DPWM strategy detects the current vector position relative to the inverter voltage reference [13]-[14]. For a three-phase dual buck VSI circuit, SPWM, SVPWM, and DSVPWM are selected for different DC bus voltage and duty cycle conditions to achieve best efficiency [15]. The evaluation process for different modulation methods has been researched by many papers [16][18]. The above literature does not deal with QZSI based SVM inverter. The objective of the present work is to reduce the THD and improve the efficiency of induction motor drive system by using SVPWM QZSI.

\section{SYSTEM CONFIGURATION}

The block diagram of the proposed system is shown in Fig.1. The space vector control strategy is adopted here. The main difference from the traditional SVPWM is to turn some of the traditional short zero state into the open zero state.

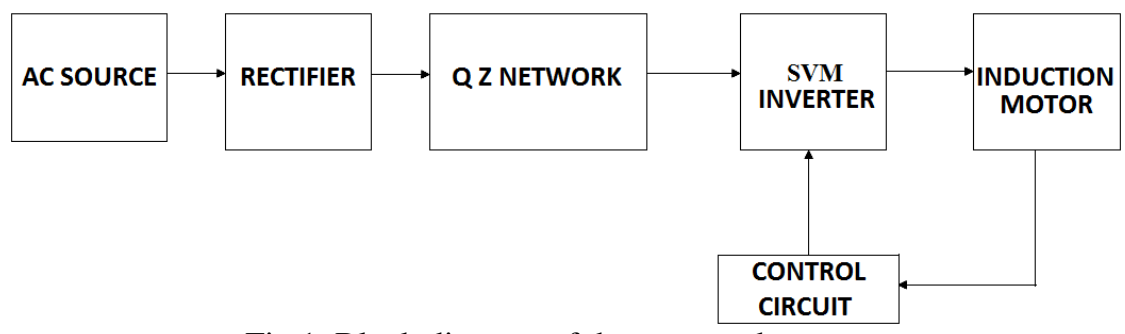

Fig.1. Block diagram of the proposed system 
International Journal of Innovative Research in Electrical, Electronics, Instrumentation and Control Engineering

Vol. 7, Issue 5, May 2019

\section{SIMULATION RESULTS}

The SIMULINK model for QZSI system with R load is shown in Fig.2. The three phase LC filter is connected at the output to reduce the harmonics. The DC input voltage is shown in Fig.3. The output voltage of Quasi $\mathrm{Z}$ network is shown in Fig.4. The voltage is boosted from $200 \mathrm{~V}$ to $420 \mathrm{~V}$. The load current waveforms are shown in Fig.8. The FFT analysis is done for the current and the spectrum is shown in Fig.5. The THD is $8.1 \%$.

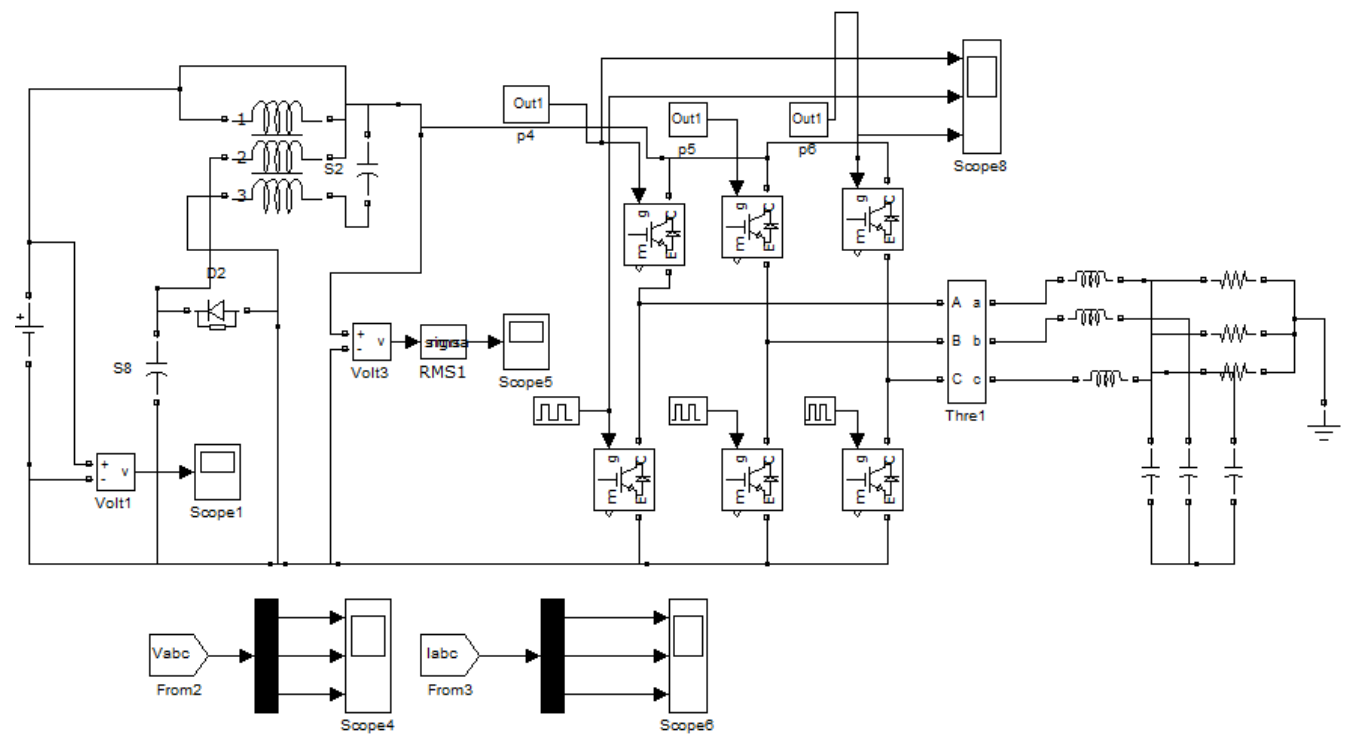

Fig.2. Circuit diagram for QZSI system

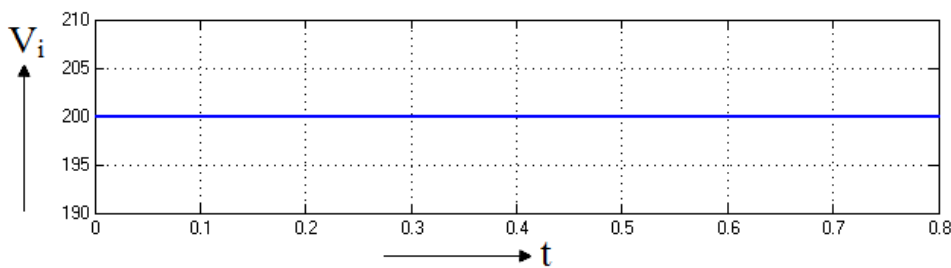

Fig.3. Input Voltage

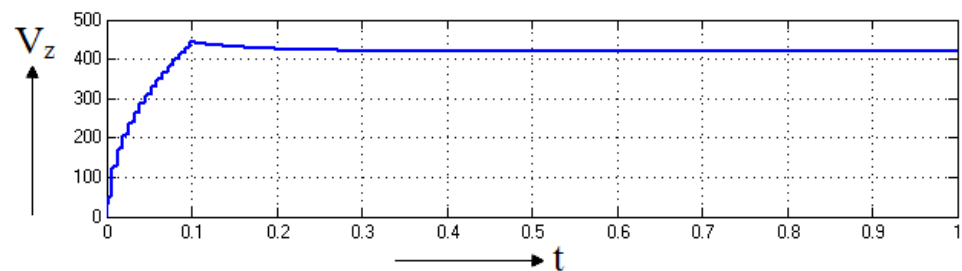

Fig.4.output voltage

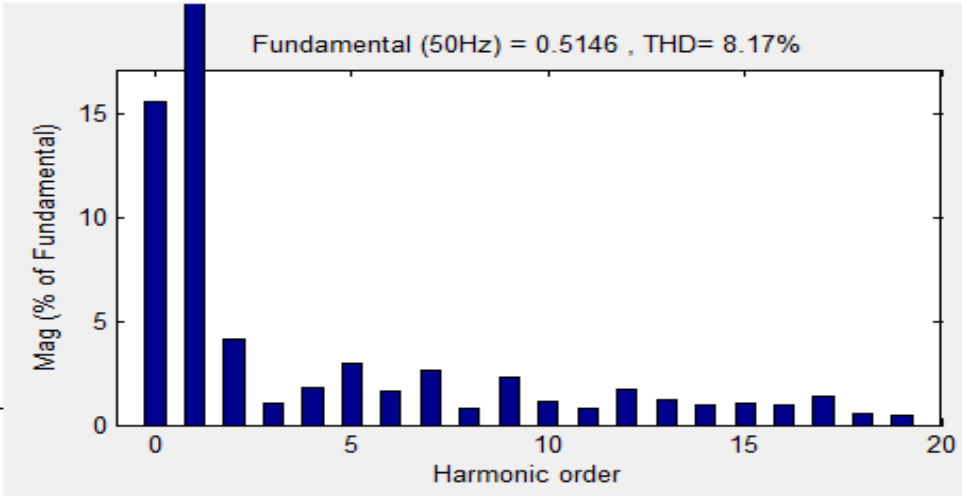

Fig.5. frequency spectrum for current 


\section{International Journal of Innovative Research in Electrical, Electronics, Instrumentation and Control Engineering}

Vol. 7, Issue 5, May 2019

The QZSI system with induction motor load is shown in Fig.6. The DC input voltage is shown in Fig.7. The speed response is shown in Fig.8. The speed settles at $1490 \mathrm{rpm}$. The THD for the current waveform is given in Fig. 9 and its value is $4.96 \%$. The reduction in THD is due to the inductance of the motor. The summary of output voltage and THD is given in Table 1. From the test results it is evident that the output voltage with SVM is 5\% higher than SPWM system. The THD is reduced by $3 \%$ by using space vector modulation.

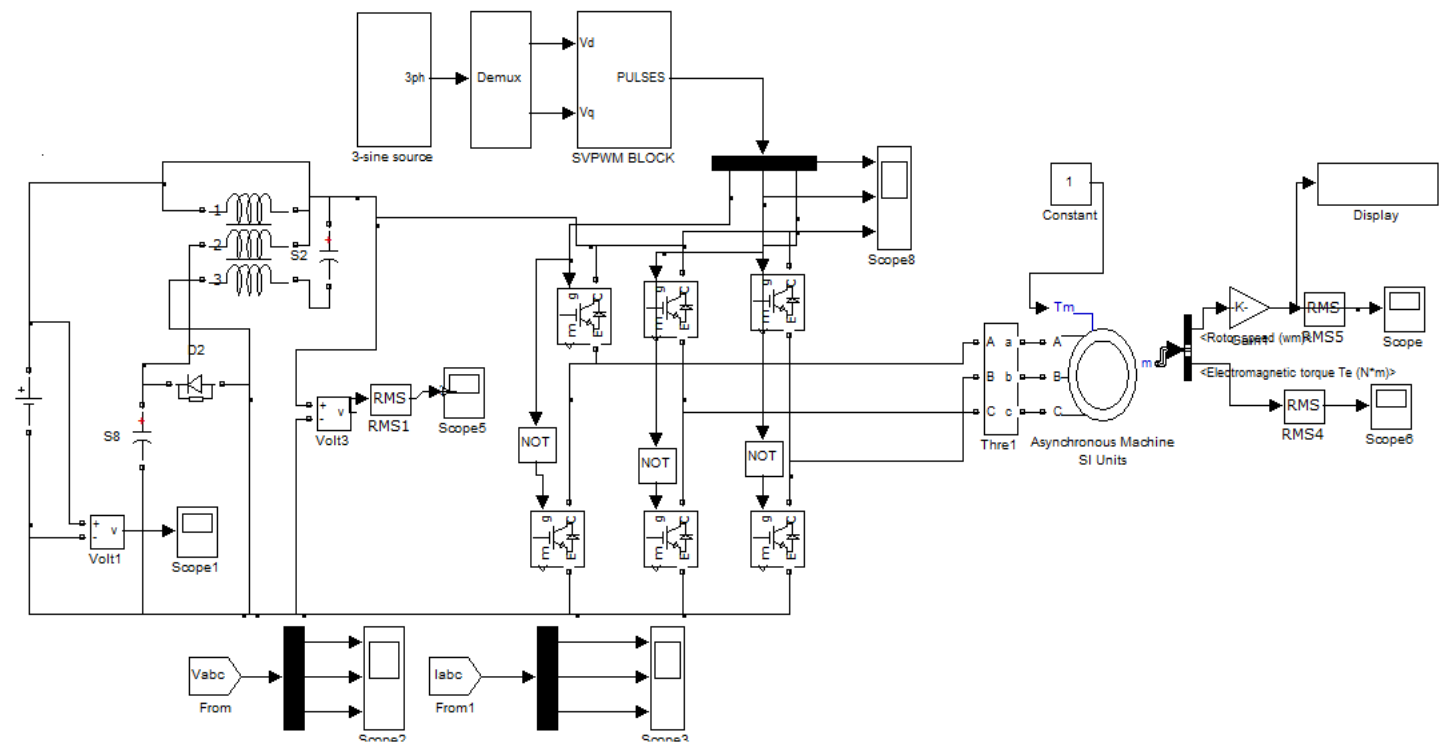

Fig.6.Circuit diagram with induction motor load

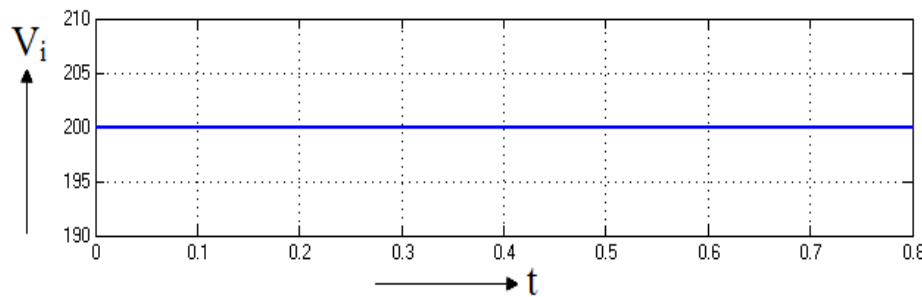

Fig.7. Input voltage

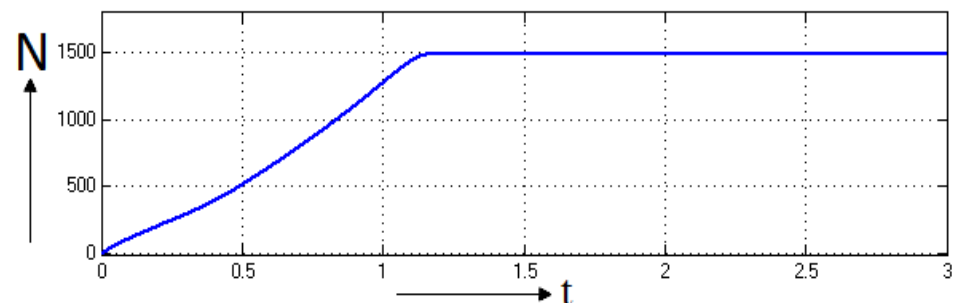

Fig.8. Motor speed

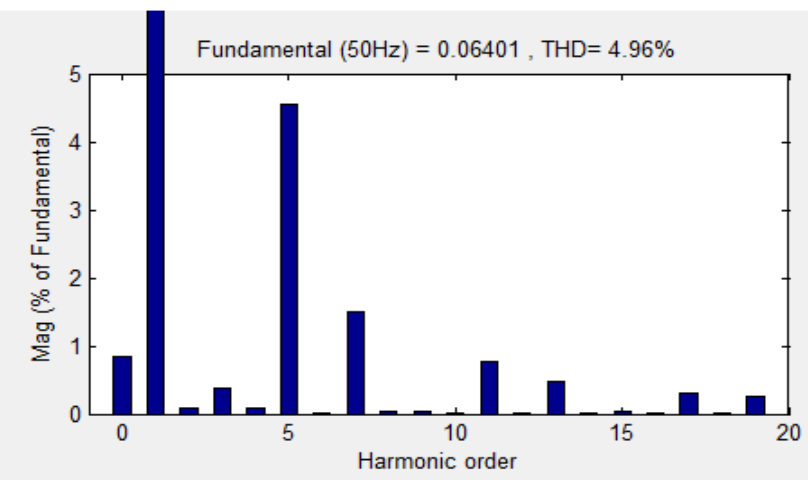

Fig.9. Frequency spectrum for current 
IJIREEICE

\section{International Journal of Innovative Research in Electrical, Electronics, Instrumentation and Control Engineering}

Vol. 7, Issue 5, May 2019

Table-1: Summary of THD values

\begin{tabular}{|c|c|c|}
\hline PARAMETERS & SINGLE PWM PULSE & SVPWM PULSE \\
\hline Vin & $200 \mathrm{~V}$ & $200 \mathrm{~V}$ \\
\hline Output Voltage & $424 \mathrm{~V}$ & $456 \mathrm{~V}$ \\
\hline THD in \% & $8.17 \%$ & $4.96 \%$ \\
\hline
\end{tabular}

\section{CONCLUSION}

The SVM based QZSI system with resistive load and induction motor load are designed, modelled and results are presented. The simulation results indicate that the output is higher with SVPWM based inverter system. The THD is as minimum as $4.9 \%$ in the proposed system. The advantages of the proposed system are reduced number of switches and reduced number of passive elements. The disadvantage is that the quasi $\mathrm{Z}$ source network requires a coupled inductor. The present work deals with comparison of SPWM and SVM based induction motor drive systems.

\section{REFERENCES}

[1]. Y. Shuitao, Q. Lei, and F. Z. Peng, "Current-Fed quasi-Z-source inverter with voltage buck-boost and regeneration capability," IEEE Trans. on Ind. Appl., vol. 47, no. 2, pp. 882-892, 2011.

[2]. S. R. Bowes and R. Bullough, "Steady-state performance of current-fed pulse-width-modulated inverter drives," Electric Power Appl., IEE Proc.B, vol. 131, pp. 113-132, 1984.

[3]. V. G. Agelidis, P. D. Ziogas, and G. Joos, "Dead-band PWM switching patterns," in Proc. 23rd Annual. IEEE Power Electron. Spec. Conf., Rec., vol. 1, pp. 427-434, 1992.

[4]. M. Jayalakshmi, G. Asha and K. Keerthana, "Control of Single Phase Z-Source Inverter Fed Induction Motor Using Simple Boost Controller," International Journal of Emerging Trends in Electrical and Electronics,vol.10, no.3.pp.44-48,Apr.2014.

[5]. S.Angayarkanni, A. Senthilnathan, R. Ilango. "SVPWM Controlled Permanent Magnet Synchronous Motor," International Journal of Innovative Technology and Research . vol.1,issue1, pp. 042-045, 2013.

[6]. S.A. Priyadarshini, A. Durgadevi, R. Anbumozhi, G.Gabriel Santhosh Kumar. "Single phase nine level PWM Inverter with DC source for Photovoltaic Systems," Imperial Journal of Interdisciplinary Research, vol.3, issue 9, 2017.

[7]. L. Dalessandro, S. D. Round, U. Drofenik, and J. W. Kolar, "Discontinuous space-vector modulation for three-level PWM rectifiers," IEEE Trans. on Power Electron., vol. 23, no. 2, pp. 530-542, Mar. 2008.

[8]. O. Ojo and S.Vanaparthy, "Carrier-based discontinuous PWM modulation for current source converters," in Proc. 39th IEEE IAS Annu. Ind. Appl.Conf. Meet Rec., vol. 4, pp. 2224-2231, 2004.

[9]. R. T. H. Li, H. Shu-hung Chung, and T. K. M. Chan, "An active modulation technique for single-phase grid-connected CSI," IEEE Trans. on Power Electron., vol. 22, no. 4, pp. 1373-1382, Jul. 2007.

[10]. B. Mirafzal, M. Saghaleini, and A. K. Kaviani, "An SVPWM-Based switching pattern for stand-alone and grid-connected three-phase single stage boost inverters," IEEE Trans. on Power Electron., vol. 26, no. 4, pp. 1102-1111, Apr. 2011.

[11]. R. T. H. Li, H. S.-H. Chung, W.-H. Lau, and B. Zhou, "Use of hybrid PWM and passive resonant snubber for a grid-connected CSI," IEEE Trans. on Power Electron., vol. 25, no. 2, pp. 298-309, Feb. 2010.

[12]. R.Ilango, M.R.K.Venkatesa Vimal Chand. "Selective Harmonics Elimination - PWM Technique In Single Phase Hybrid Cascaded Multi Level Inverter Using Bee Algorithmll," International Journal Of Innovative Research In Engineering Science And Technology, ISSN no. 2320981X, vol. 3 no. 4, pp.13-18, 2015.

[13]. A Subramaniya Siva, M Bhavani, Mitigation of Harmonics by Shunt Active Power Filter Synchronous Detection Method, International Journal of Engineering Trends and Technology,vol.4, no.6 pp.2231-5381, June 2013.

[14]. K.Dhayalini, "Active power filter for vehicle to grid application using bidirectional conversion techniques in manufacturing industries,'International Journal of Pure Applied Mathematics,vol.118,no,18,pp.1971-1980,2018.

[15]. P. Sun, C. Liu, J.-S. Lai, C.-L. Chen, and N Kees, “Three-Phase dual buck inverter with unified pulse width modulation," IEEE Trans. on Power Electron., vol. 27, no. 3, pp. 1159-1167, Mar. 2012.

[16]. M. Baumann, T. Nussbaumer, and J. W. Kolar, "Comparative evaluation of modulation methods of a three-phase buck+boost PWM rectifierPart I: Theoretical analysis,” IET Power Electron., vol. 1, pp. 255-267, 2008.

[17]. M. Venkatachalapathy and A. Edward Samuel, An Alternative Method for Solving Fuzzy Transportation Problem using Ranking Function,International Journal of Applied Mathematical Sciences, Volume 9, Number 1 (2016), pp. 61-68.

[18]. L. Helle, K. B. Larsen, A. H. Jorgensen, S. Munk-Nielsen, and F. Blaabjerg, "Evaluation of modulation schemes for three-phase to three phase matrix converters," IEEE Trans. on Ind. Electron., vol. 51, no. 1, pp. 158-171, Feb. 2004. 